\title{
KEAMANAN PENGGUNAAN ANESTESI REGIONAL PADA PERSALINAN PENGIDAP HIV
}

\author{
Lucky Kumaat \\ Bagian Anestesi RSUP Prof.Dr.R.D.Kandou Manado \\ Fakultas Kedokteran Universitas Sam Ratulangi Manado
}

\begin{abstract}
Human Immunodeficiency Virus (HIV) infection and Acquired Immunodeficiency Syndrome (AIDS) are the major problems of global health. It is estimated that approximately 75.9\% of Human Immunodeficiency Virus (HIV)-infected women aged are in productive ages (20-39 years) with possibilities to become pregnant. Since the prevalence of Human Immunodeficiency Virus infection in pregnant women is increasing, anesthesiologists are increasingly confronting these diseases in their patients. HIV infection in pregnant women often raises questions about the safety of regional anesthesia for them. Fears of the spread of infection to the Central Nervous System (CNS) or the sequel of the neurological system have led some clinicians not to use regional anesthesia. Some research shows that pregnant women with HIV infection are not a contraindication for regional anesthesia since there is no CNS and neurological sequel or infection after a long enough time post operation.
\end{abstract}

Keywords: HIV infection, AIDS, parturition, regional anaesthesia.

\begin{abstract}
Abstrak: Infeksi Human Immunodeficiency Virus (HIV) dan Acquired Immunodeficiency Syndrome (AIDS) adalah masalah utama dari kesehatan global. Diperkirakan sekitar 75,9\% wanita yang terinfeksi HIV berada pada usia produktif (20-39 tahun) yang berpeluang untuk hamil. Karena prevalensi infeksi HIV pada wanita hamil semakin meningkat, maka ahli anestesi semakin banyak diperhadapi dengan pasien demikian. Infeksi HIV pada wanita hamil seringkali memunculkan pertanyaan mengenai keamanan penggunaan anestesi regional pada mereka. Kekuatiran terhadap penyebaran infeksi ke sistim susunan saraf pusat (SSP) atau sekuel neurologik menyebabkan sebagian klinisi menentang penggunaan anestesi regional. Beberapa penelitian telah membuktikan bahwa wanita hamil dengan HIV bukan merupakan kontraindikasi bagi penggunaan anestesi regional karena tidak dijumpai adanya infeksi SSP atau sekuel neurologik setelah selang waktu yang cukup panjang pasca operasi.
\end{abstract}

Kata kunci: Infeksi HIV, AIDS, persalinan, anestesi regional.

Acquired Immunodeficiency Syndrome (AIDS) yang disebabkan oleh infeksi Human Immunodeficiency Virus (HIV), termasuk penyakit infeksi yang mengancam jiwa. Hingga kini infeksi HIV dan AIDS masih merupakan masalah kesehatan global termasuk Indonesia. Menurut UNAIDS/WHO pada Desember 2002, jumlah orang dengan HIV/ AIDS (ODHA) mencapai 42 juta jiwa dimana 19,2 juta di antaranya adalah wanita. Kematian dalam tahun 2002 mencapai 3,1 juta jiwa, dengan 1,2 juta di antaranya wanita.
Meskipun telah dilakukan berbagai upaya pencegahan primer maupun sekunder, namun transmisi HIV masih tetap berlangsung. Dalam tahun 2002 tersebut dari lima juta jiwa terinfeksi baru HIV, dua juta jiwa adalah wanita. Salah satu transmisi HIV terjadi secara vertikal dari ibu ke anak yang mencapai $15-45 \%$, terjadi pada saat kehamilan, intrapartum dan pasca persalinan. ${ }^{1}$

Diagnosis infeksi HIV pada kehamilan seringkali memunculkan pertanyaan mengenai keamanan anestesi dan analgesi regi- 
onal yang dapat digunakan. Kontroversi ini pertama kali muncul ketika dinyatakan penggunaan jarum spinal meningkatkan risiko pasien untuk mengalami sekuel neurologik penyakit ini. ${ }^{2}$ Meskipun terdapat kekuatiran, namun saat ini telah diketahui bahwa infeksi HIV bukan merupakan kontraindikasi pemberian anestesi neuraksial. ${ }^{3}$

Masih sedikit informasi mengenai risiko anestesi bagi pengidap HIV. Pemeriksaan pre-operasi terperinci untuk menyingkap penyakit multisistim yang disebabkan oleh HIV atau penggunaan obat HIV sangat penting. Anestesi umum bisa diterima tetapi interaksi obat dan penyakit multisistim yang disebabkan oleh HIV harus dipertimbangkan masak-masak pre-operasi. Anestesi regional aman tetapi juga harus dipertimbangkan preoperasi terjadinya infeksi lokal, permasalahan perdarahan dan neuropati. ${ }^{4}$

\section{INFEKSI HIV DAN AIDS}

HIV adalah penyebab terjadinya AIDS, yaitu kelemahan sistem imun. HIV masuk ke dalam tubuh melalui kontak transeksual, kontak darah maupun produk darah atau transmisi vertikal dari ibu ke anak. Pada awal masuknya HIV ke dalam tubuh manusia, mekanisme respons imun yang terjadi adalah up regulation, tetapi lambat laun akan terjadi down regulation karena kegagalan dalam mekanisme adaptasi dan terjadinya kelemahan sistem imun. Keadaan ini menyebabkan tubuh pengidap HIV menjadi rentan terhadap infeksi oportunistik. Pada pengidap HIV di Indonesia infeksi oportunistik berpotensi lebih awal munculnya karena bukan saja semata-mata diakibatkan semakin melemahnya sistem imun, tetapi juga pengaruh lingkungan tempat tinggal, yang nampak pada masih tingginya angka kejadian infeksi lainnya di Indonesia. ${ }^{1}$

Disamping itu para pengidap HIV di Indonesia cenderung mudah jatuh ke stadium AIDS akibat terjadinya infeksi oportunistik yang diakibatkan oleh karena tinggal berdampingan dalam lingkungan yang berpeluang terjadinya infeksi lain. Berbagai infeksi oportunistik yang sering ditemukan pada pengidap HIV dan AIDS di Indonesia adalah toksoplasmosis, sepsis, pneumonia pneumokistik karinii, tuberkulosis paru, hepatitis B, hepatitis $\mathrm{C}$, infeksi virus sitomegalo, diare kronis, kandidiasis oroesofageal serta berbagai manifestasi infeksi pada kulit. ${ }^{1}$

\section{Transmisi infeksi HIV}

Transmisi HIV masuk ke dalam tubuh manusia melalui tiga cara, yaitu: (1) secara vertikal dari ibu yang terinfeksi HIV ke anak (selama mengandung, persalinan dan menyusui); (2) secara transeksual (homoseksual maupun heteroseksual); dan (3) secara horisontal yaitu kontak antar-darah atau terkontaminasi dengan produk darah yang terinfeksi. Transmisi horisontal umunya terjadi akibat kurang diperhatikannya asas sterilitas, terutama pada pemakaian jarum suntik bersama-sama secara bergantian, tato, tindik, transfusi darah, transplantasi organ, tindakan hemodialisis atau perawatan gigi. HIV dapat diisolasi dari darah, semen, cairan serviks, cairan vagina, air susu ibu (ASI), air liur, serum, urin, air mata, cairan alveolar atau cairan serebrospinalis. Sejauh ini transmisi yang umum terjadi adalah melalui darah, cairan semen, cairan vagina dan serviks serta ASI. ${ }^{1}$

Secara teoritis petugas kesehatan berisiko tertular karena kontak dengan cairan tubuh pasien terinfeksi HIV. Walaupun demikian dalam prakteknya, penularan HIV akibat kecelakaan kerja pada petugas kesehatan sangat rendah $(0,3 \%)$. Penularan dari pasien ke pasien terutama diakibatkan oleh alat kesehatan yang tercemar dan tidak didesinfeksi secara baik atau kurang memadai, dan melalui transfusi darah. ${ }^{1}$

\section{Infeksi sekunder HIV pada sistem saraf}

Umumnya sel otak tidak mudah menjadi sasaran infeksi sistemik termasuk HIV, karena $99 \%$ dilindungi oleh sawar darah otak. Bila infeksi HIV dapat menimbulkan komplikasi ke sistim SSP, sering berakibat fatal. Otak dilindungi dari pengaruh mikroorganisme oleh sawar darah otak yang terdiri atas rangkaian endotel dengan taut kedap pada kapiler SSP, perisit, lamina basalis, astroendofeet dan kanal. Peran sawar darah otak tersebut juga ditunjang oleh sel imunokom- 
peten dan antibodi.

Susunan saraf pusat sering terlibat pada infeksi HIV. Sekitar $40 \%$ penderita AIDS (stadium 3 atau 4) atau pengidap HIV (stadium 2) simtomatis bahkan stadium 1 pun mampu berkembang ke arah manifestasi neurologik akibat pengaruh glycoprotein 41 (gp41) yang neurotoksik. Separuh dari kelainan neurologik penderita AIDS disebabkan pengaruh infeksi langsung (gp41 HIV) maupun tidak langsung (produk HIV), sedangkan sisanya akibat pengaruh infeksi sekunder (penurunan respon imun). ${ }^{1}$

Dampak patologis yang ditimbulkan merupakan akibat langsung dari protein virus yaitu glycoprotein 120 (Gp120), Gp41, Tat dan Nef. Pengaruh langsung HIV mengakibatkan ensefalopati HIV, meningitis HIV dan lain-lainnya. Dampak tidak langsung diakibatkan oleh produksi dan sekresi sitokin yaitu IL1ß, IL-2 dan TNF- $\alpha$. Pengaruh tidak langsung yang dimungkinkan akibat sitokin dan penurunan sistim imun yaitu terjadinya infeksi sekunder di otak akibat toksoplasma, mikobakterium tuberkulosa dan jamur. ${ }^{1}$

\section{PENGARUH KEHAMILAN TERHADAP PROGRESIVITAS INFEKSI HIV}

Dari berbagai penelitian menunjukkan bahwa kehamilan itu sendiri tidak mempengaruhi progresivitas HIV ke arah AIDS. Penurunan $\mathrm{CD}^{+}$memang terjadi pada ibu hamil dengan HIV, tetapi penurunan tersebut lebih diakibatkan oleh karena dilusi. Pengaruh kehamilan terhadap $\mathrm{CD}^{+}$pertama kali dilaporkan oleh Burns dkk. Pada kehamilan yang tidak disertai HIV, persentase $\mathrm{CD}^{+}$ akan meningkat kembali mulai trimester ketiga hingga 12 bulan setelah melahirkan, sedangkan pada ODHA penurunan tetap terjadi selama kehamilan dan setelah melahirkan. Penelitian yang dilakukan European Collaborative Study dan Swiss HIV Pregnancy Cohort dengan jumlah sampel yang lebih besar menunjukkan persentase penurunan $\mathrm{CD}^{+}$selama kehamilan sampai enam bulan setelah melahirkan. Kehamilan ternyata hanya sedikit meningkatkan kadar virus HIV (viral load). Kadar HIV meningkat terutama setelah dua tahun persalinan, walaupun seca- ra statistik tidak bermakna. Dengan demikian kehamilan ternyata tidak mempercepat progresivitas HIV ke arah AIDS. ${ }^{1}$

\section{MEKANISME INFEKSI HIV KE DA- LAM LIMFOSIT T-CD4}

Berbagai sel dapat menjadi target HIV, tetapi virion HIV cenderung menyerang limfosit $\mathrm{T}$ karena terdapat reseptor CD4 pada permukaannya. Target HIV pada limfosit TCD4 ini kemudian menarik perhatian karena mekanisme penurunan jumlah limfosit $T$ belum sepenuhnya diketahui, dan jumlah limfosit $\mathrm{T}$ tersebut penting untuk menentukan progresivitas penyakit. HIV cenderung memilih target limfosit $\mathrm{T}$ karena pada permukaan limfosit ini terdapat reseptor CD4 yang merupakan pasangan ideal bagi transmembrane glycoprotein 120 (gp120). Reseptor CD4 tersebut masih belum memungkinkan HIV masuk ke dalam limfosit $\mathrm{T}$ di tubuh host, tetapi perlu dibantu oleh peran koreseptor chemokine receptor type 5 (CCR5) dan chemokine receptor type 4 (CXCR4) yang juga berada di permukaan limfosit $\mathrm{T}$. Dengan peran gp41 transmembran (transmembrane glycoprotein 41), maka permukaan luar dari HIV berfusi dengan membran plasma limfosit T-CD4. Inti (core) HIV selanjutnya masuk ke dalam limfosit $\mathrm{T}$ sambil membawa enzim reverse transcriptase. Pada saat memasuki sitoplasma limfosit T-CD4 yang terinfeksi, bagian inti HIV yaitu RNA (single-stranded RNA) akan berusaha menyesuaikan dengan konfigurasi double-stranded DNA, yang memerlukan bantuan enzim reverse transcriptase yang telah dipersiapkan tersebut. Selanjutnya terjadi penyatuan virion dengan DNA polimerase sehingga terbentuk cDNA atau proviral $D N A$. Proses berikutnya adalah upaya masuk ke dalam inti limfosit $\mathrm{T}$ dengan bantuan enzim integrase. Terjadilah rangkaian proses integrasi, transkripsi yang dilanjutkan dengan translasi protein virus, serta replikasi HIV virion. Jumlah virion HIV yang berlipat ganda kemudian meninggalkan inti. Setelah mengalami modifikasi dan saling melengkapi, kemudian virion berusaha keluar menembus membran limfosit (budding). Virion 
yang baru terbentuk siap menginfeksi limfosit T-CD4 berikutnya. Demikian proses ini terus berlangsung sehingga jumlah limfosit T-CD4 cenderung terus menurun. ${ }^{1}$

\section{PERTIMBANGAN SEBELUM MELA- KUKAN ANALGESIA REGIONAL}

Selain bermanfaat besar, teknik analgesia regional juga mempunyai kerugian, dari yang ringan sampai berat, termasuk kematian. Seperti tindakan intervensi medik lainnya, maka penting dilakukan evaluasi manfaat dibandingkan dengan risiko yang didasarkan pada perkiraan frekuensi dan beratnya potensial kerugian yang terjadi. Oleh karena itu evaluasi menyeluruh harus dilakukan baik pada kondisi medis dan indikasi obstetrik maupun terhadap obat-obat yang berimplikasi pada pengelolaan analgesia regional.

\section{Kondisi medis}

Terdapat sejumlah kondisi medis penting yang harus diperhatikan sebelum pemberian analgesia dan anastesi pada persalinan, yaitu:

\section{Penyakit kardiovaskular}

Pasien dengan penyakit kardiovaskular serta hemodinamik stabil yang mendapatkan analgesia regional memberikan hasil yang lebih baik dari pada mereka yang tidak mendapatkan analgesia yang efektif selama proses persalinan. ${ }^{5}$ Pada pasien dengan hipertensi berat, penggunaan epidural analgesia akan memperbaiki luaran tanpa meningkatkan frekuensi seksio sesarea, edema paru atau gagal ginjal. ${ }^{6}$

\section{Penyakit neurologik}

Penggunaan teknik regional pada pasien dengan penyakit neurologik penyerta harus didasarkan atas penilaian resiko dan manfaatnya.

\section{Penyakit muskuloskeletal}

Analgesia epidural atau spinal kontinyu telah digunakan secara sukses pada hampir $50 \%$ pasien dengan skoliosis dan atau telah menjalani operasi spinal sebelumnya. Pada pasien tanpa riwayat masalah punggung sebelumnya, ternyata kejadian nyeri punggung yang baru tidak meningkat setelah analgesia regional. ${ }^{7,8}$

\section{Penyakit hematologik}

Sampai saat ini, belum memungkinkan untuk menentukan batas bawah jumlah trombosit yang meningkatkan risiko hematoma. Untuk pasien normal, tidak terjadi peningkatan risiko komplikasi dengan trombosit > 100.000/dL. Jumlah trombosit > 80.000/dL telah diusulkan aman untuk melakukan blok regional bila tidak disertai faktor risiko.,

\section{Obesitas}

Pada pasien obesitas, bila tidak terdapat kontraindikasi pemasangan kateter epidural profilaksis akan menurunkan komplikasi anestesi dan perinatal dibandingkan bila pemasangan dilakukan pada keadaan emergensi. ${ }^{11}$,

\section{Indikasi obstetrik}

Penencanaan analgesia epidural mungkin sesuai dengan beberapa indikasi obstetrik. Sebanyak $27 \%$ pasien membutuhkan intervensi anestesia selama kala dua persalinan dan $6 \%$ membutuhkan seksio sesarea emergensi. $^{12}$

Obat-obat yang mempunyai implikasi terhadap pengelolaan analgesia regional

\section{Low molecular weight heparin (LMWH)}

Antikoagulan merupakan faktor risiko yang sangat penting pada terjadinya hematoma epidural setelah blok regional. Menghentikan LMWH lebih dari 12 jam sebelum persalinan adalah aman bila dihubungkan dengan komplikasi perdarahan maternal. Blok regional sebaiknya dihindari paling kurang 12 jam setelah dosis standar profilaksis LMWH.

\section{Aspirin dosis rendah}

Pada pasien yang menggunakan aspirin dosis rendah tidak dijumpai efek merugikan yang berhubungan dengan anestesi regional. $^{13}$ 
KOMPLIKASI DAN EFEK SAMPING ANESTESI REGIONAL PADA PERSA-

\section{LINAN}

\section{Neurotoksisitas}

Komplikasi neurologik yang berhubungan dengan analgesia dan anestesi neuroaksial sangat jarang terjadi, terutama bila dibandingkan dengan komplikasi neurologik oleh persalinan. Namun injeksi obat ke dalam ruang epidural atau subaraknoid mempunyai potensi untuk terjadinya iritasi atau kerusakan struktur saraf. Oleh karena itu ahli anestesi harus berhati-hati dalam menggunakan obat baru yang disuntikkan ke dalam ruang subaraknoid. Injeksi obat yang keliru, larutan anestetik lokal dengan konsentrasi yang tinggi, zat preservatif yang neurotoksik berpengaruh buruk secara langsung terhadap jaringan saraf. Trauma langsung dapat disebabkan oleh jarum atau kateter. ${ }^{14-16}$

Komplikasi neurologik lainnya setelah analgesia neuroaksial termasuk transient neurologic syndrome (TNS), hematom spinal/epidural, abses spinal/epidural, keluhan nyeri punggung dan parestesia. Suatu studi retrospektif observasional terhadap 6497 wanita yang mendapat analgesia regional di rumah sakit tersier menemukan insiden parastesia lebih sering pada wanita yang menerima CSE dibanding epidural. ${ }^{14-16}$

\section{Pruritus}

Pruritus merupakan efek samping yang umum dari pemberian opioid intratekal dan lebih tinggi pada pemberian epidural. ${ }^{14-16}$

\section{Retensi urin}

Etiologi retensi urin setelah spinal analgesia berhubungan dengan cepatnya onset relaksasi otot detrusor yang disebabkan kerja opioid pada spinal sakral dan anestetik lokal. ${ }^{14}$

\section{Pengosongan lambung yang lama dan efek mual-muntah}

Persalinan dan pemberian opioid keduanya memperlambat pengosongan lambung. Hal ini dapat menjadi predisposisi terjadinya mual dan muntah. Penyebab lain mual dan muntah pada persalinan termasuk oleh kehamilan itu sendiri dan nyeri selama proses persalinan. $^{14-16}$

\section{Postdural puncture headache (PDPH)}

Insiden PDPH setelah penusukan dura dengan jarum besar Touhy 18 gauge (bila melakukan epidural, CSE, spinal analgesia kontinyu) telah dilaporkan mencapai 50\% pada parturian. Penggunaan noncutting, pencil-point needle dapat menurunkan insiden PDPH setelah penusukan duramater. Keuntungan teknik CSE adalah penggunaan jarum spinal yang kecil sehingga dapat menurunkan kemungkinan terjadinya PDPH. ${ }^{14-16}$

\section{Efek pada janin}

Absorpsi sistemik dari opioid dan anestesi lokal yang diikuti transfer melalui plasenta, dapat menyebabkan efek langsung pada janin. Hal ini dapat meliputi perubahan denyut jantung janin dan depresi pernapasan setelah persalinan. ${ }^{14-16}$

Pemberian opioid epidural jarang berefek pada denyut jantung janin, namun perlu diperhatikan adanya bradikardi janin yang terjadi setelah analgesia spinal. Efek samping maternal dari pemberian opioid dapat berefek langsung pada janin, seperti depresi pernapasan parturian akan menyebabkan hipoksia pada janin. Denyut jantung janin harus dimonitor sebelum melakukan blok neuroaksial. $^{14-16}$

\section{PERMASALAHAN DALAM PENGGU- NAAN ANESTESI DAN ANALGESIA REGIONAL PADA PARTURIAN}

Umumnya pasien yang terinfeksi HIV memiliki riwayat medis/sosial yang mempengaruhi perjalanan infeksi HIV. Penyalahgunaan obat (khususnya penyalahgunaan obat intravena) masih menjadi faktor risiko utama dan memiliki implikasi anestesi. Penyakit menular seksual, seperti hepatitis B dan sifilis juga mempengaruhi penatalaksanaan anestesi. HIV adalah virus neurotropik dan invasi ke SSP terjadi pada tahap awal infeksi primer. Oleh karena itu pemeriksaan 
fisik yang rinci dan dokumentasi defisit neurologik harus diperhatikan sebelum induksi anestesi regional. Adanya demensia yang berhubungan dengan AIDS bisa mempengaruhi pemahaman pasien untuk menentukan pilihan untuk melaksanakan pembedahan atau anestesi. ${ }^{17}$

Keterlibatan sistim pernapasan dengan keadaan patologis orofaringeal dan esofageal membuat pasien lebih rentan mengalami regurgitasi, kesulitan intubasi dan aspirasi. Infeksi paru oportunistik memperpanjang penggunaan ventilasi mekanis pasca operasi. Pemeriksaan menyeluruh sistim kardiovaskular (kardiomiopati subklinis) dan renal (nefropati), serta pemeriksaan hematologik (neutropenia, trombositopenia) diindikasikan sebagai bagian pemeriksaan anestesi preoperasi. Walaupun trombositopenia bisa terjadi pada pasien HIV positif, hitung trombosit jarang terlalu rendah untuk bisa mempengaruhi pilihan anestesi. Walaupun demikian, jika hitung trombosit di bawah 50.000, risiko perdarahan dan terjadinya hematom epidural meningkat, sehingga penggunaan teknik anestesi alternatif harus dipertimbangkan berdasarkan kasus demi kasus. Belum terdapat bukti peningkatan komplikasi infeksi pada pasien hamil yang mendapatkan anestesi atau analgesia neuroaksial. ${ }^{17}$

Risiko dilakukannya anestesi regional pada parturian yang terinfeksi HIV masih sangat kurang informasinya. Kekuatiran yang paling sering dikemukakan pada penggunaan anestesi regional sehingga sering mendapat resistensi dari sebagian klinisi yaitu terjadinya penyebaran infeksi ke SSP atau terjadinya sekuel neurologik. Kontroversi ini muncul pertama kali ketika ditemukan bahwa adanya penyebaran penyakit ke SSP dapat menyebabkan sekuel neurologik pada penggunaan jarum spinal untuk parturian dengan HIV. ${ }^{17}$ Penelitian prospektif yang dilakukan terhadap parturian yang terinfeksi HIV-1 memperlihatkan bahwa anestesi regional bisa dilakukan tanpa sekuel efek samping. Hal ini juga diperkuat dengan tidak ditemukannya komplikasi neurologik atau infeksi yang berhubungan dengan perjalanan obstetri maupun anestesi. Fungsi imun parturian tetap stabil pada masa peripartum. Walaupun jumlah pasien yang diteliti masih sedikit, namun dengan adanya evaluasi medis dan pertimbangan yang terperinci, anestesi regional merupakan pilihan yang bisa diterima bagi parturian yang terinfeksi HIV $-1 .^{3}$

Parturian yang terinfeksi dengan HIV-1 harus dilakukan penilaian secara seksama terhadap adanya disfungsi neurologik dan hematologik sebelum menggunakan anestesi regional. Para ahli anestesi harus menyadari akan bahaya toksisitas dari pengobatan terapetik HIV serta dampaknya terhadap anestesi. Penelitian yang dilakukan terhadap sejumlah wanita menunjukkan tidak adanya sekuel neurologik selama dua tahun pasca anestesi, di mana 31 dari 96 wanita yang memiliki limfosit sel $\mathrm{T}$ CD4/CD8 pada trimester dua dan 24-48 jam postpartum, tidak menunjukkan memburuknya status imun ibu yang menerima anestesi regional. Pada penelitian lainnya yang dilakukan terhadap 96 parturian dengan HIV positif, dari 36 orang yang menerima anestesi regional, tidak ditemukan adanya bukti klinis maupun imunologik dari eksaserbasi penyakit neurologik sehingga anestesi regional merupakan salah satu pilihan yang tepat pada parturian dengan HIV positif. ${ }^{18}$

\section{KESIMPULAN}

Dewasa ini prevalensi infeksi HIV pada parturian cenderung meningkat, yang berdampak pada pemilihan jenis anestesi yang tepat dan aman untuk mereka pada saat persalinan. Analgesia dan anestesi regional merupakan pilihan yang cukup diminati oleh para ahli anestesi karena tidak dijumpainya komplikasi seperti infeksi SSP atau sekuel neurologik setelah selang waktu yang cukup panjang pasca operasi.

\section{DAFTAR PUSTAKA}

1. Nasronudin. HIV dan AIDS: Pendekatan biologi molekuler, klinis dan sosial. 2007;19:115-16, 137-39, 162-3.

2. Greene ER Jr. Spinal and epidural anaesthesia in patients with the acquired immunodeficiency syndrome, anaesthesia-analgesia. 1986;65:1090-1. 
3. Hughes SC, Dalley PA, Landers D, Dallel BJ, Crombleholme WR, Johnson JL. Parturients infected with HIV and regional anaesthesia: clinical and immunologic response. Anaesthesiology. 1995;82:32-6.

4. Parthasaraty S, Ravisankhar M. HIV and anaesthesia. Indian $\mathbf{J}$ Anaesth. 2007;51(2):91-9.

5. Bucklin BA. What's new in obstetric anaesthesia lecture. Anaesthesiology. 2006; 104:865-71.

6. Hugg B. Safety of labor epidural anaesthesia for women with severe hypertensive disease. National Institute of Child Health and Human Development Maternal-Fetal Medicine units network. Am J Obstet Gynecol. 1999;181:1096-101.

7. Smith PS. Regional blockade for delivery in women with scoliosis or previous spinal surgery. Int J Obstet Anesth. 2003;12:1722.

8. Howell CJ. Randomized study of long term outcome after epidural versus nonepidural analgesia during labor. BMJ. 2002;325,357.

9. Rolbin SH. Epidural anaesthesia in pregnant patients with low platelet counts. Obstet Gynecol. 1988;71:918-20.

10. Douglas JM. Neuraxial anaesthesia in partueints with thrombocytopenia in evidence-based obstetric anaesthesia. Blackwell Publishing, 2005; p.165-77.

11. Saravanakumar K, Rao SG, Cooper GM. Obesity and obstetric anaesthesia. 2006;61:36-48.
12. Carvalho B. Vaginal twin delivery: a survey and review of location, anaesthesia coverage and intervention. Int $\mathrm{J}$ Obstet Anaest. 2008;17:212-16.

13. Sibai BM. Low-dose aspirin in nulliparous women: safety of continuous epidural block and correlation between bleeding time and maternal-neonatal bleeding complication. National Institute of Child Health and Human Development Maternal-Fetal Medicine Network. Am J Obstet Gynecol. 1995;172:1553-7.

14. Birnbach DJ, Hernandez M. Neuraxial analgesia for labor in spinal and epidural anaesthesia, Wong CA (ed). New York: Mc Graw-Hill, 2007; p.257-74.

15. Paull J. Epidural analgesia for labor in: Textbook of Obstetric Anaesthesia, Birnbach DJ et al. (ed) Philadelphia: Churchill Livingstone, 2000; p.145-54.

16. Miro M, Guasch E, Gilsanz F. Comparison of epidural analgesia with combined spinal-epidural analgesia for labor: a retrospective study of 6497 cases. Int J Obstet Anesth. 2008;17:15-9.

17. Kuczkowski KM. Anaesthetic consideration for the HIV-infected pregnant patient, Department of Anaesthesiology UCSD Center, San Diego California USA, Review Article, Yonsei Medical Journal. 2004;45(1):1-6.

18. Gershon RY, Manning-Williams D. Anaesthesia and the HIV-infected parturient: a retrospective study. Int $\mathbf{J}$ Anaesth. 1997;6:76-81. 